UDC: $577.29: 564.38: 57.014$

\title{
EVALUATION OF METALLOTHIONEIN RESPONSE IN LYMNAEA STAGNALIS POND SNAIL EXPOSURED TO TRACE METALS AND THIOCARBAMATE FUNGICIDE
}

\section{L. Gnatyshyna}

I. Ya. Horbachevsky Ternopil State Medical University, Maidan Voli, 1, Ternopil 46001, Ukraine Research Laboratory of Comparative Biochemistry and Molecular Biology Ternopil Volodymyr Hnatiuk National Pedagogical University 2, M. Kryvonis St., Ternopil 46027, Ukraine e-mail: gnatyshynall@tdmu.edu.ua

Gnatyshyna L. L. Evaluation of metallothionein response in Lymnaea stagnalis pond snail exposured to trace metals and thiocarbamate fungicide. Studia Biologica, 2019: 13(1); 27-38 • DOI: https://doi.org/10.30970/sbi.1301.585

Pulmonate mollusks posses high uptake rates of dissolved metals and their bonding, mainly $\mathrm{Cd}, \mathrm{Zn}$ and $\mathrm{Cu}$ by the metal-buffering protein, metallothionein (MT). However, most investigations are focused at the terrestrial species, whereas aquatic snails are studied scantly. Therefore, the main goal of our study was to evaluate a specificity of metal-binding function of the metallothionein in Lymnaea stagnalis pond snail. The mollusks were subjected to typical metallothionein inducers $\mathrm{Cd}^{2+}, 15 \mu \mathrm{g} \cdot \mathrm{L}^{-1} ; \mathrm{Cu}^{2+}$, $10 \mu \mathrm{g} \cdot \mathrm{L}^{-1} ; \mathrm{Zn}^{2+}, 130 \mu \mathrm{g} \cdot \mathrm{L}^{-1}$ and oxidative stress inducer thiocarbamate Tattoo fungicide, $91 \mu \mathrm{g} \mathrm{L}^{-1}$ during 14 days. Applied concentrations corresponded to the ecologically relevant concentrations. Metal concentrations and metallothionein characteristics in a digestive gland were analyzed. In present study, all exposures to metals caused the elevation of the concentration of metals $(\mathrm{Zn}, \mathrm{Cu}$ or $\mathrm{Cd})$ in tissues and the total level of metallothionein detected from their thiols (MT-SH). Particularly, Zn level in tissues was increased by $\sim 2-3$ times in all cases of the exposure to metals. Cd increased the level of metal-contained form of the metallothionein (MT-Me). Tattoo affected the levels of metals and MT-SH in the tissue to low extent but caused the redistribution of metals between the metallothionein (increase) and other compounds. The distortion of the elution profile of metallothionein on the DEAE-cellulose was shown at each exposure. To summarize, snails demonstrated a wide spectrum of responses and juxtaposition of different characteristics depending on the exposure. The responses to metals and

(C) 2019 L. L. Gnatyshyna. Published by the Ivan Franko National University of Lviv on behalf of Біологічні Студії / Studia Biologica. This is an Open Access article distributed under the terms of the Creative Commons Attribution License (http://www.budapestopenaccessinitiative.org/ and Creative Commons Attribution 4.0 License), which permits unrestricted reuse, distribution, and reproduction in any medium, provided the original work is properly cited.

ISSN 1996-4536 (print) • ISSN 2311-0783 (on-line) • Біологічні Студії / Studia Biologica • 2019 • Том 13/№1 • С. 27-38 
Tattoo were distinguished by the detection of metallothionein concentration. The primary reasons for the effect of thiocarbamate on the metal homeostasis needs further investigations.

Keywords: pulmonate mollusk, trace metals, thiocarbamate fungicide, toxicity

\section{INTRODUCTION}

Freshwater snails are an important species in the aquatic ecosystems due to their rapid grazing rates, sensitivity to different kinds of pollution [3, 5, 17, 24, 28]. At present, more studies address the values and services of freshwater snails within an ecosystem, their ability to accumulate either metals or metal-containing compounds and a risk to higher trophic levels [32]. Freshwater pulmonate mollusk, pond snail Lymnaea stagnalis (Linné, 1758), as known as the "great pond snail," represents the predominate species in the freshwater zoobenthos of Central Europe [15].

Metallothionein (MT) is the most acknowledged among the biomarkers of pollution in mollusks, as the indicator of specific pollution by highly toxic metal cadmium due to high affinity of this metal-binding protein to cadmium $[1,35]$. In the polluted environment, this metal of the anthropogenic origin can replace physiological metals zinc $(\mathrm{Zn})$ and copper $(\mathrm{Cu})$ in metal-thiolate clusters of the MT. Moreover, it is one of the most effective inducers of MT expression in different aquatic organisms [1]. It is noteworthy to mention that MT of the terrestrial snails are investigated thoroughly, particularly by R. Dallinger and colleagues [5, 18, 24, 27]. They demonstrated especially high variability of the molecular forms induced by the exposures to cadmium and copper. However, the responses of metallothionein in snails to other substances as the essential targets for these proteins are unknown. Among the aquatic mollusks, the MT in bivalve mollusks were shown to enhance the total concentration without an increase in the level of metalcontained form in different exposures, including thiocarbamate and cobalt-contained nanonized polymer [10,11]. Indeed, about $30 \%$ of amino acid composition of metallothionein is represented by cysteine. Therefore, a vulnerability of metal binding function despite high total level of protein is expected from the particular metal binding/release dynamics intrinsic to these proteins [35].

Due to a lack of information concerning the properties of the MT in the aquatic snails, the goal of this study was to evaluate the peculiarities of the metal-binding response of the MT in the freshwater pulmonate $L$. stagnalis mollusk pond snail. The snails were subjected to typical metallothionein inducers, namely $\mathrm{Cd}, \mathrm{Zn}, \mathrm{Cu}$, and known oxidative stress inducer and metal chelator thiocarbamate fungicide $[4,7,33]$.

\section{MATERIALS AND METHODS}

The specimen collection was carried out at turn of August, when the reproductive system is not significantly affected. About 50 adult specimens of the Lymnaea stagnalis pond snail with shell height of $25-35 \mathrm{~mm}$ were collected in the pristine area located in the upstream portion of river Seret (Ternopil region, Ukraine, $49^{\circ} 49^{\prime} \mathrm{N}, 25^{\circ} 23^{\prime} \mathrm{E}$ ). Individuals were transported to the laboratory in cages with native water and adapted to aerated, softened tap water with continued support of mineral/salt balance $\left(17 \pm 1{ }^{\circ} \mathrm{C}\right.$, $\mathrm{pH} 7.3 \pm 0.2, \mathrm{CaCO}_{3}$ level $86.8 \pm 1.0 \mathrm{mg} \cdot \mathrm{L}^{-1}$, dissolved oxygen level $8.67 \pm 0.51 \mathrm{mg} \cdot \mathrm{L}^{-1}$, ammonia $\left(\mathrm{NH}_{3} / \mathrm{NH}_{4}^{+}\right)$and nitrite levels below $\left.0.1 \mathrm{mg} \cdot \mathrm{L}^{-1}\right)$ for seven days. After that, they

ISSN 1996-4536 (print) • ISSN 2311-0783 (on-line) • Біологічні Студії / Studia Biologica • 2019 • Том 13/№1 • С. 27-38 
were divided in five groups, control group $(C)$, and groups subjected to waterborne metals copper $\left(\mathrm{Cu}^{2+}, 10 \mu \mathrm{g} \cdot \mathrm{L}^{-1}\right.$ correspondent to $\left.0.156 \mu \mathrm{M}\right)$, zinc $\left(\mathrm{Zn}^{2+}, 130 \mu \mathrm{g} \cdot \mathrm{L}^{-1}\right.$ correspondent to $2.0 \mu \mathrm{M})$, cadmium $\left(\mathrm{Cd}^{2+}, 15 \mu \mathrm{g} \cdot \mathrm{L}^{-1}\right.$ correspondent to $\left.0.134 \mu \mathrm{M}\right)$ and Tattoo fungicide (commercial formulation containing $45 \%$ of propamocarb- $\mathrm{HCl}$ (propyl-3-(dimethylamino) propylcarbamate and $55 \%$ of mancozeb, or Zn, Mn ethylenebis(dithiocarbamate) [-SCSNH $\left.\left(\mathrm{CH}_{2}\right)_{2} \mathrm{NHCSSMn-]n(Zn)m(Mn)],} 91 \mu \mathrm{g} \mathrm{L}-1\right)$. Applied metal and Tattoo concentrations were based on their ecologically relevant concentrations for fresh water (US EPA, 2007) and previous experience with the same exposures effect on bivalve mollusks $[8,9,11]$.

Mollusks were exposed during 14 days in $80 \mathrm{~L}$ tanks with aerated, softened tap water. Water and studied substances were renewed every two days. Mollusks were fed on lettuce before water changes. Mortality of snails was not observed during the experiment. Sampled tissues were stored at $-40{ }^{\circ} \mathrm{C}$. Each procedure of tissue preparation was carried out at $4{ }^{\circ} \mathrm{C}$. Protein concentration in the supernatant (soluble protein) was measured by the method of Lowry et al. (1951) [21], using bovine serum albumin as protein standard. The absorbance values were measured on UV/Vis spectrophotometer "Lomo-56" (Russian Federation).

MTs were obtained as the thermostable proteins by size-exclusion chromatography on Sephadex G-50 for determining of the metal ( $\mathrm{Zn}, \mathrm{Cu}, \mathrm{Cd}$ ) concentrations [31]. Tissue samples were pooled and each pool was created from equal mass of aliquoted tissue (total mass $350 \mathrm{mg}$ ), and then homogenized in ice-cold $10 \mathrm{mM}$ Tris- $\mathrm{HCl}$ buffer, $\mathrm{pH}$ 8.0, containing $10 \mathrm{mM}$ 2-mercaptoethanol to prevent the MT from oxidation and $0.1 \mathrm{mM}$ phenylmethylsulfonyl fluoride (PMSF) to prevent protease activity. Despite the protease inhibitors do not appear to be required to recover metallothionein [19], the utilizing of PMSF is a common condition of the homogenate preparation and provides the avoiding of the low molecular weight products of the proteolysis in the thermostable supernatant.

This supernatant was incubated under the $85^{\circ} \mathrm{C}$ for $5 \mathrm{~min}$ and subsequently centrifuged at $16,000 \times \mathrm{g}$ for $45 \mathrm{~min}$ at $4{ }^{\circ} \mathrm{C}$. The obtained thermostable supernatant material was applied to a size-exclusion chromatography on Sephadex G-50 superfine column $(1.5 \times 50 \mathrm{~cm})$ in the same buffer at a flow rate $0.33 \mathrm{ml} \cdot \mathrm{min}^{-1}$. Fractions $(5 \mathrm{ml})$ were collected and analyzed for absorbance at 280 and $254 \mathrm{~nm}$. Column calibration was achieved by applying a mixture of the appropriate protein standards: chymotrypsinogen (25.8 kDa), myoglobin (17.0 kDa), cytohrome $c(12.3 \mathrm{kDa})$, ubiquitin $(8.4 \mathrm{kDa})$, insulin chain B oxidized (3.5 kDa). MT-containing fractions were identified based on unique spectral features (comparative high density ratio $D_{254} / D_{280}$ ), thermostability, and low molecular mass. The correspondent fractions were pooled (total $10 \mathrm{~mL}$ ) for metal determination or anion-exchange chromatography.

The anion-exchange chromatography of the thermostable solution was carried out on a column $(1.5 \times 50 \mathrm{~cm})$, packed with DEAE-cellulose. After removing of non-bound proteins by the column rinsing with $70 \mathrm{ml}$ of buffer, elution was carried out in gradient mode with 0-1.0 M NaCl in a $10 \mathrm{mM}$ Tris- $\mathrm{HCl}$ ( $\mathrm{pH}$ 8.0) buffer containing $10 \mathrm{mM}$ 2-mercaptoethanol and $1 \mathrm{mM}$ 2-isopropanol at a flow rate of $0.5 \mathrm{ml} \cdot \mathrm{min}^{-1}$. Column calibration was achieved by applying standard metallothionein from rabbit liver. The fractions of each peak with high absorbance at $254 \mathrm{~nm}$ were pooled for the ultraviolet (UV) absorption spectra and the metals determination.

Metallothioneins' total protein concentration (MT-SH) was determined from thiols measure with DTNB after the ethanol/chloroform extraction from tissue [36]. The level

ISSN 1996-4536 (print) • ISSN 2311-0783 (on-line) • Біологічні Студії / Studia Biologica • 2019 • Том 13/№1 • С. 27-38 
of MT-SH was calculated assuming the relationship: $1 \mathrm{~mol} \mathrm{MT}=20 \mathrm{~mol} \mathrm{GSH}$ and expressed as mg of MT per $g$ of fresh tissue (FW).

The concentration of $\mathrm{Cu}, \mathrm{Zn}$ and $\mathrm{Cd}$ was measured in samples of the weighed tissue (250 $\mathrm{mg}$ from each specimen). The samples were dried for $24 \mathrm{~h}$ at $105^{\circ} \mathrm{C}$, and then digested with $5 \mathrm{ml} \mathrm{HNO}_{3}$ for $3 \mathrm{~h}$ at $105^{\circ} \mathrm{C}$ under pressure and using acid-cleaned Teflon bomb. The content of $\mathrm{Cu}$ and $\mathrm{Zn}$ was evaluated by the atomic absorption spectrophotometry against certified standards on the spectrometer C-115, ("Lomo", Russian Federation), and $\mathrm{Cd}$ was analyzed by the graphite furnace atomic absorption spectrometer S-600 ("Selmi", Ukraine). Detection limits for metals were $0.1 \mu \mathrm{g} \cdot \mathrm{g}^{-1} \mathrm{FW}$. The reliability of the metals measurements was assessed by analyzing ERM-CE 278 certified reference material; metal recovery was between 90 and $110 \%$. Quality control was assessed by the method of Standard Addition [2]. Metal concentration in tissue and MT was expressed as $\mu \mathrm{g} \cdot \mathrm{g}^{-1}$ fresh weight (FW). MT metal-binding characteristics (MT-Me) was calculated from the concentrations of metals in the MT considering that one molecule of MT binds $7 \mathrm{Zn}^{2+}$ or $\mathrm{Cd}^{2+}$ ions or $12 \mathrm{Cu}^{+}$ions [25].

Thermostable proteins chemical analysis was carried out in triplicate on the joint sample from five individuals, and all other measurements were carried out in 8 specimens. A reliability of deviation of two series was calculated using the Student's $t$-test. Difference between group was considered reliable at $P<0.05$. The results were expressed as means \pm standard deviation (S.D.). All statistical calculations were performed with Statistica v 12.0 and Excel for Windows-2000.

\section{RESULTS AND DISCUSSION}

From our previous experience, it is known that low weight cellular MT thiols belong to most sensitive biochemical indicators in L. stagnalis demonstrating a multiple variability of the metal composition and chromatographic forms under the environmental detrimental effects, and also, under the such nonspecific for this protein exposure as the effect of ionizing radiation $[13,14]$. In the current study, to attest their participation in metal detoxification and stress response, we evaluated total MT protein concentration (MT-SH), the level and composition of their metal-contained form (MT-Me) and their chromatographic characteristics.

Under size-exchange chromatography MT-containing peak was identified from low molecular mass (about $10 \mathrm{kDa}$ ), UV-spectrum with the typical for metal-thiolate clusters maximum at $\sim 254 \mathrm{~nm}$ and absence of the peak at $280 \mathrm{~nm}$, typical for the common proteins (Fig. 1A,C) [19, 31]. The ion-exchange chromatography revealed two peaks corresponding to a distribution of the rabbit MT - MT-1 and MT-2 in the control group of snails. This behavior of the protein confirmed the purity and typical features of the MT [19]. The profile of MT under the ion-exchange chromatography was distorted at the exposures to metals and Tattoo, and the intermediate fraction, MT-2A, appeared (Fig. 1B). Typical UV-spectra of the metallothionein in the exposed snails were indicated according to the size-exclusion chromatography (Fig. 1C). Under the ion-exchange chromatography, the MT spectra were changed demonstrating a vulnerability of separate forms after a second step of purification (Fig. 1D).

The most expected response of mollusks at exposures to metals $\mathrm{Cd}, \mathrm{Zn}, \mathrm{Cu}$ is accumulation of correspondent metal in tissue of the digestive gland and its metallothionein [1]. Indeed, an exposure to metals caused an elevation of metal concentrations in a digestive gland (Fig. $2 A, B, C$ ). At the same time, concentration of effective metal was

ISSN 1996-4536 (print) • ISSN 2311-0783 (on-line) • Біологічні Студії / Studia Biologica • 2019 • Том 13/№1 • С. 27-38 
A

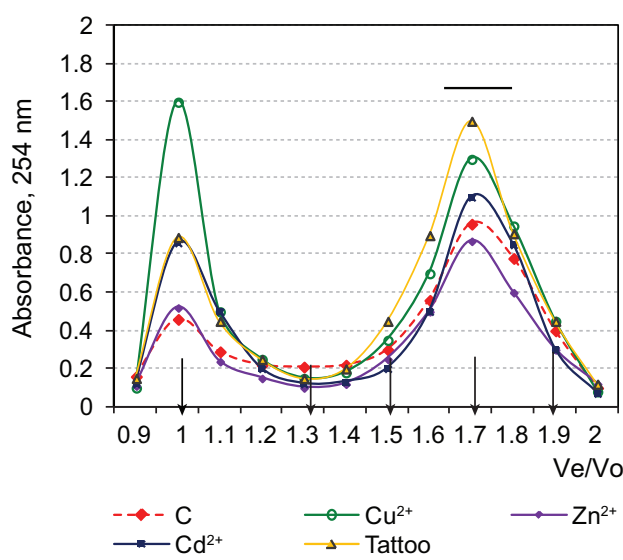

C

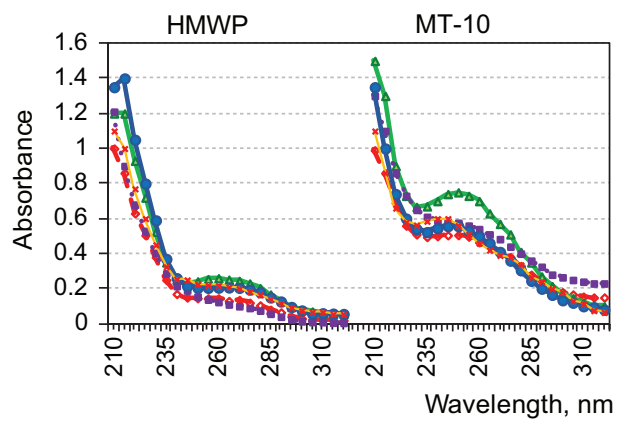

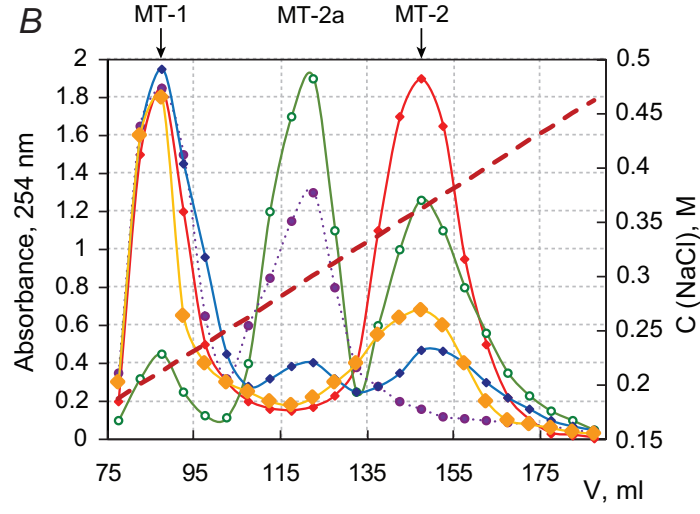

$\begin{array}{lll}\longrightarrow \mathrm{C} & \longrightarrow \mathrm{Cu}^{2+} & \cdots \cdot \cdots \mathrm{Zn}^{2+} \\ \longrightarrow \mathrm{Cd}^{2+} & \longrightarrow \text { Tattoo } & ---\mathrm{C}(\mathrm{NaCl})\end{array}$

$D$

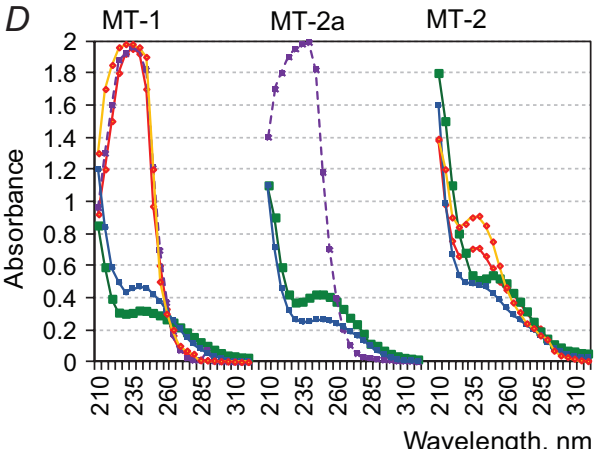

$\begin{array}{ll}\longrightarrow \mathrm{C} & \longrightarrow \mathrm{Cu}^{2+} \\ \mathrm{Cd}^{2+} & \longrightarrow \text { Tattoo }\end{array}$

$--*--\mathrm{Zn}^{2+}$

Fig. 1. Elution profiles $(A, B)$ and UV-spectra $(C, D)$ of the thermostable proteins from a digestive gland of pond snail Lymnaea stagnalis obtained by chromatography on Sephadex G-50 $(A, C)$ and DEAEcellulose $(B, D)$. In Fig. $1 A$ : arrows highlight the elution volume of markers: $25.8 \mathrm{kDa}, 17.0 \mathrm{kDa}, 12.3$ $\mathrm{kDa}, 8.4 \mathrm{kDa}, 3.4 \mathrm{kDa}$ appropriate to $1.06 ; 1.31 ; 1.51 ; 1.74 ; 1.91 \mathrm{Ve} / \mathrm{Vo}$, correspondingly; Ve, elution volume; Vo, void volume of the column. In Fig.1B: a gradient of elution of $10 \mathrm{mM}$ Tris- $\mathrm{HCl}(\mathrm{pH} 8.0)$ buffer is shown by the diagonal line; arrows indicate the elution volume of standard metallothionein from rabbit liver. In Fig. 1C, HMWP: high molecular weight proteins

Рис. 1. Профілі елюції $(A, B)$ та УФ-спектри $(C, D)$ термостабільних протеїнів травної залози легеневого молюска Lymnaea stagnalis під час гель-розподільчої хроматографрії на сефрадексі G-50 $(A, C)$ та ДЕАЕ-целюлозі $(B, D)$. У рис. $1 A$ : стрілками вказано об'єм елюйованих маркерів: 25,8 кДа, 17,0 кДа, 12,3 кДа, 8,4 кДа, 3,4 кДа, які відповідають 1,06; 1,31; 1,51; 1,74; 1,91 Ve/Vo відповідно; Ve - об'єм елюції, Vo - зовнішній об'єм колонки. У рис. $1 B$ : градієнт елюючого 10 мM Tris-HCl (рН 8.0) буферу зображено діагональною лінією; стрілки вказують на об'єм елюйованого стандартного металотіонеїну печінки кролика. У рис. 1 C HMWP: протеїни з високою молекулярною масою

elevated only for $\mathrm{Zn}$ and $\mathrm{Cd}$, whereas an exposure to $\mathrm{Cu}$ did not cause its excessive accumulation. The level of metals in a digestive gland was correspondent to control value at the exposure to Tattoo, The elevated level of $Z n$ (by $~ 2-3$ times) in tissue was the most specific response at the exposures to metals in comparison with the effect of thiocarbamate. The Tattoo per se is a source of $\mathrm{Zn}$ due to its formula. Therefore, the 
elevated Zn concentrations were found in the sediment (87-190 $\mathrm{mg} \cdot \mathrm{kg}^{-1}$ exceeding the threshold values for aquatic life of $98 \mathrm{mg} \cdot \mathrm{kg}^{-1}$ at several sites) in the areas of the intensive application of Tattoo [23]. In the present study, the level of $\mathrm{Zn}$ in the exposure to Tattoo was by 40 times lesser than in the exposure to the ionic form of $\mathrm{Zn}$. Additionally, the responses to ionic and organic forms of metal could be different, as it was reported at the exposures of bivalve mollusk to ionic cobalt and $\mathrm{Co}^{2+}$-containing nanoscale polymeric complex [10]. Interestingly, the bivalve mollusk Anodonta cygnea demonstrated opposite responses at the same exposures conditions avoiding accumulation of metals in tissues [8, 9].
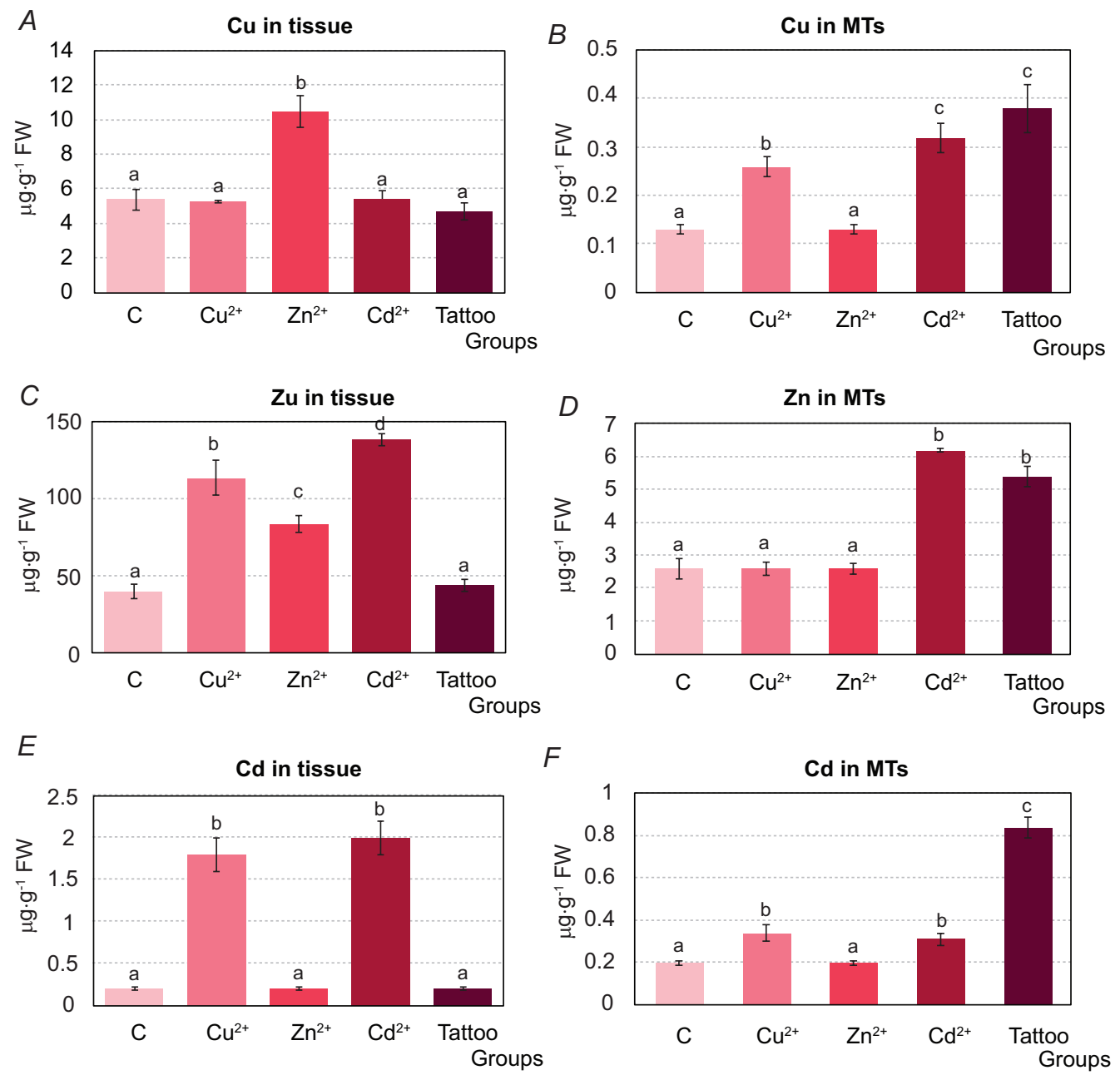

Fig. 2. Characteristics of metal $\mathrm{Cu}(A, B), \mathrm{Zn}(C, D), \mathrm{Cd}(E, F)$ partitioning in a digestive gland $(A, C, D)$ and metallothioneins $(B, D, F)$ of Lymnaea stagnalis, $\mathrm{M} \pm \mathrm{SD}(\mathrm{n}=8)$. Here and further: if the letters above the bars are the same, this indicates that the values do not differ significantly $(P>0.05)$

Рис. 2. Розподіл металів $\mathrm{Cu}(A, B), \mathrm{Zn}(C, D), \mathrm{Cd}(E, F)$ у тканині травної залози $(\mathrm{A}, \mathrm{C}, \mathrm{D})$ та металотіонеїнах $(B, D, F)$ Lymnaea stagnalis, $\mathrm{M} \pm \mathrm{SD}(\mathrm{n}=8)$. Тут і далі: однакові літери над стовпчиками вказують на значення, які істотно не відрізняються $(P>0,05)$

ISSN 1996-4536 (print) • ISSN 2311-0783 (on-line) • Біологічні Студії / Studia Biologica • 2019 • Том 13/№1 • С. 27-38 
Metal composition of the MT in snails was affected substantially (Fig. 2D,E,F). The levels of $\mathrm{Cu}$ and $\mathrm{Cd}$ were increased in the metallothionein at the exposures to $\mathrm{Cu}, \mathrm{Cd}$, Tattoo; the level of $\mathrm{Zn}$ was increased by the exposures to $\mathrm{Cd}$ and Tattoo. However, despite known preference of metallothionein in the Cd binding, only $16 \%$ of $\mathrm{Cd}$ in the tissue of snail was bound with the metallothionein at the correspondent exposure. In the study of Leung et al. (2003) [20], low level of Cd (of $0.01 \mu \mathrm{g} / \mathrm{L}$ ) also did not change metal accumulation in the MT of the aquatic snails. Only the exposure to high concentration $1,000 \mu \mathrm{g} / \mathrm{L}$ of $\mathrm{Cd}$ during 10 days increased the level of MT-like proteins and the concentrations of metals $(\mathrm{Cd}$, and also $\mathrm{Ni}$ and $\mathrm{Cr}$ ). At the same time, there was no difference in $\mathrm{Cu}, \mathrm{Zn}$ and $\mathrm{Pb}$ concentrations between the exposed and control groups.

Nevertheless, the total level of metal accumulation in the metallothionein was the highest at the exposures to $\mathrm{Cd}$ (level of $\mathrm{Cu}$ and $\mathrm{Zn}$, and also, but much less $\mathrm{Cd}$ ) and Tattoo ( $\mathrm{Cu}, \mathrm{Zn}$ and $\mathrm{Cd}$ ). The concentration of metal-contained MT (MT-Me) was increased at these exposures by 2.2-2.6 times in comparison to control value and it was not changed at the exposure to $\mathrm{Zn}$ and $\mathrm{Cu}$ (Fig. 3B). However, MT accumulated low amount of $\mathrm{Cu}(\sim 1-10 \%)$ and $\mathrm{Zn}(\sim 3-12 \%)$ containing in tissue, whereas their part in $\mathrm{Cd}$ accumulation reached $84 \%$ (at the exposure to Tattoo). A proportion of metal concentrations in the composition of MT $(\mathrm{Zn}: \mathrm{Cu}: \mathrm{Cd})$ did not change prominently, therefore in all studied groups $\mathrm{Zn}$ was the main metal in composition of MT.

$A$

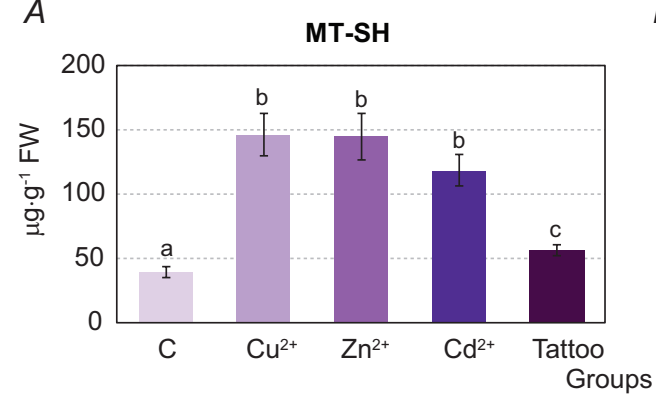

$B$

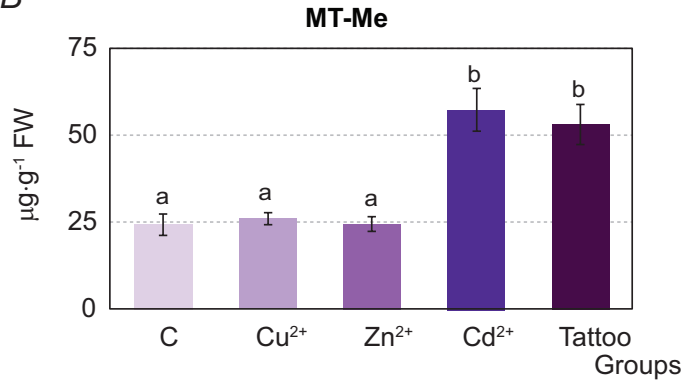

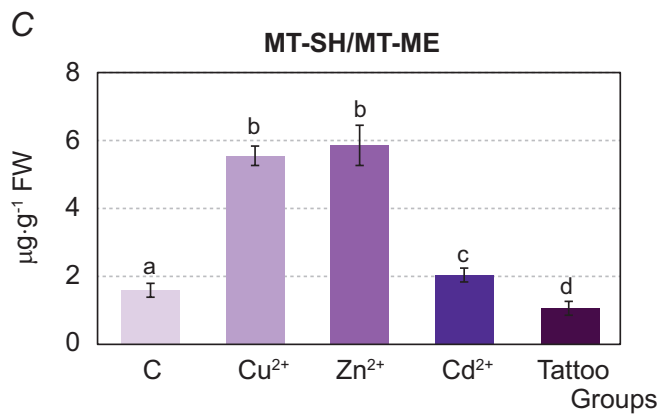

Fig. 3. Total metallothioneins MT-SH $(A)$ and metalated metallothioneins MT-Me $(B)$ concentrations and their ratio MT-SH/MT-Me $(C)$ in a digestive gland of Lymnaea stagnalis, $M \pm S D, n=8(n=3$, combined sample from 5 specimens for metal-contained metallothionein)

Рис. 3. Загальна концентрація металотіонеїнів MT-SH $(A)$, металовмісної форми металотіонеїнів MT-Me (B) та їхнє співвідношення MT-SH/MT-Me (C) у травній залозі Lymnaea stagnalis, M \pm SD, $\mathrm{n}=8$ ( $\mathrm{n}=3$, об'єднані зразки з п'яти тварин, взяті для визначення металовмісної фрорми металотіонеїнів)

ISSN 1996-4536 (print) • ISSN 2311-0783 (on-line) • Біологічні Студії / Studia Biologica • 2019 • Том 13/№1 • С. 27-38 
In the studies of R. Dallinger and colleagues [5, 26, 27], the selected accumulation of $\mathrm{Cu}$ and $\mathrm{Cd}$ in different MT forms of the Roman snail Helix pomatia under the experimental exposures [5, 26, 27] were proved. Mixed Cd, Cu-MT isoform has been also detected in the terrestrial pulmonate mollusk but in low abundance [18]. However, it was found that the metal intake in L. stagnalis has special features in comparison to the terrestrial Gastropoda. Although this snail possesses MT [14], it also binds ions of metals by thiol-contained peptides phytochelatins, and their level increased at the exposure to Cd [16]. Moreover, in the study of Niederwanger et al. (2017), MT of freshwater snail Biomphalaria glabrata lacked a clear metal-binding preference for $\mathrm{Cu}, \mathrm{Zn}$ and $\mathrm{Cd}$, that is clearly unprecedented in the Gastropoda MT. Absence of changes in MT gene transcription of $B$. glabrata after 21 days duration of $\mathrm{Cd}$ exposure $(75 \mu \mathrm{g} / \mathrm{L})$ confirmed a particular metal intake in aquatic snails [24]. Our results confirm low rate of the metallothionein involving in the metals binding in the aquatic snail.

Importantly, at the case of the exposure to Tattoo elevated metalation of metallothionein was not accompanied by an increased total metal concentration in tissue. Consequently, the metal-chelating thiocarbamate compound $[7,30]$ caused a redistribution of metals within the tissue among different molecular targets. Similar increased participation of MT in metal binding at the exposure to Tattoo was observed in the bivalve mollusk [12].

Total concentration of metallothioneins (MT-SH) was increased by 3.6 times in all cases of metal exposures and much less (by 1.4 times) at the exposure to Tattoo comparative to control value (Fig. $3 A$ ). The exposure of $L$. stagnalis to extremely high concentration of $\mathrm{Cd}\left(50 \mathrm{mg} \mathrm{L}^{-1}\right)$ during 20 days also caused an increase in total metallothionein concentration [6].

The calculated MT-SH/MT-Me concentration ratio (Fig. $3 C$ ) was increased substantially at exposures to metals: in $\mathrm{Cu}$ - and $\mathrm{Zn}$-exposed groups by 3.5 times and in the Cd-exposed group - by 1.3 times than in control group. In a group exposed to Tattoo, it was lower than in the control. Indeed, at the exposures to metals, an increased level of the metallothionein was associated with the apoform of this protein, the same as in the bivalve mollusks [8], whereas, at the exposure to thiocarbamate the metal-binding function of metallothioneins was more evident. At increased MT concentration (7.6-fold) under the thiocarbamate action was reported in rat liver at $17 \mathrm{~h}$ after a single injection [34]. This effect on the MT was explained later as the dithiocarbamates inactivated reactive oxygen intermediates, chelate $\mathrm{Zn}$ (II) and synergistically augmented the induction of MT-1 mRNA levels via the antioxidant response element [29]. In current study, at low thiocarbamate concentration, the metallothionein synthesis was likely not targeted. However, a particular impact on the metal chelating was evident.

To summarize, common features of metallothionein responses in the aquatic mollusks can be noted as a partial saturation by metal exposures. Low level and vulnerability of the metallothioneins in snails confirms a finding of the R. Dallinger and colleagues $[5,18,24,26,27]$ concerning a particular metal sequestration in the aquatic snails.

\section{CONCLUSION}

In present study, all exposures to metals caused an elevation of concentration of metals ( $\mathrm{Zn}$, Cu or $\mathrm{Cd}$ ) in tissues, whereas thiocarbamate fungicide did not affect it. The effect of metals and Tattoo on the levels of metallothionein metalation was opposite.

ISSN 1996-4536 (print) • ISSN 2311-0783 (on-line) • Біологічні Студії / Studia Biologica • 2019 • Том 13/№1 • С. 27-38 
A distorted distribution of metals in tissue under the exposure to Tattoo needs more precise study of the initial targets of its effects.

\section{ACKNOWLEDGMENTS}

We thank the members of prof. O. Stoliar's laboratory who contributed the study. This work has been granted by the Ministry of Education and Science of Ukraine and the State Fund of Fundamental Research of Ukraine awarded to O. Stoliar (\#M/13-2009, \#F29/321-2009, 132B).

1. Amiard J.C., Amiard-Triquet C., Barka S., Pellerin J., Rainbow P.S. Metallothioneins in aquatic invertebrates: Their use as biomarkers. Aquat. Toxicol., 2006; 76(2): 160-202.

[DOI: http://dx.doi.org/10.1016/j.aquatox.2005.08.015; PMID: 16289342; Google Scholar]

2. Beukelman T.E., Lord S.S. The standard addition technique in flame spectrometry. Appl. Spectrosc., 1960; 14(1): 12-17.

[DOI: https://doi.org/10.1366/000370260774614715; Google Scholar]

3. Bhagat J., Ingole B.S., Singh N. Glutathione S-transferase, catalase, superoxide dismutase, glutathione peroxidase, and lipid peroxidation as biomarkers of oxidative stress in snails: A review. Invert. Surviv. J., 2016; 13.

[Google Scholar]

4. Calviello G., Piccioni E., Boninsegna A., Tedesco B., Maggiano N., Serini S., Wolf F.I., Palozza $P$. DNA damage and apoptosis induction by the pesticide Mancozeb in rat cells: involvement of the oxidative mechanism. Toxicol. Appl. Pharmacol., 2006; 211: 87-96.

[DOI: http://dx.doi.org/10.1016/j.taap.2005.06.001; PMID: 16005924; Google Scholar]

5. Dallinger R., Wang Y., Berger B., Mackay E.A., Kägi J.H.R. Spectroscopic characterization of metallothionein from the terrestrial snail, Helix pomatia. Eur. J. Biochem., 2001; 268: 41264133.

[DOI: https://doi.org/10.1046/j.1432-1327.2001.02318.x; PMID: 11488904; Google Scholar]

6. Desouky M.M. Metallothionein is up-regulated in molluscan responses to cadmium, but not aluminum, exposure. J. Basic Appl. Zool., 2012; 65 (2): 139-143.

[DOI: https://doi.org/10.1016/j.jobaz.2012.07.008; Google Scholar]

7. Domico L.M., Cooper K.R., Bernard L.P., Zeevalk G.D. Reactive oxygen species generation by the ethylene-bis-dithiocarbamate (EBDC) fungicide mancozeb and its contribution to neuronal toxicity in mesencephalic cells. Neurotoxicology, 2007; 28: 1079-1091.

[DOI: http://dx.doi.org/10.1016/j.neuro.2007.04.008; PMID: 17597214; Google Scholar]

8. Falfushynska H., Gnatyshyna L., Stoliar O. Effect of in situ exposure history on the molecular responses of bivalve mollusks to trace metals. Ecotoxicol. Environ. Saf., 2013, 89: 73-83. [DOI: https://doi.org/10.1016/j.ecoenv.2012.11.024; PMID: 23260242; Google Scholar]

9. Falfushynska H., Gnatyshyna L., Stoliar O. In situ exposure history modulates the molecular responses to carbamate fungicide Tattoo in bivalve mollusk. Ecotoxicology, 2013; 22 (3): 433-445.

[DOI: https://doi.org/10.1007/s10646-012-1037-6; PMID: 23306937; Google Scholar]

10. Falfushynska H., Gnatyshyna L., Stoliar O., Mitina N., Skorokhoda T., Filyak Ye., Zaichenko A., Stoika $R$. Evaluation of biotargeting and ecotoxicity of $\mathrm{Co}^{2+}$-containing nanoscale polymeric complex by applying multi-marker approach in bivalve mollusk Anodonta cygnea. Chemosphere, 2012; 88: 925-936.

[DOI: https://doi.org/10.1016/j.chemosphere.2012.02.087; PMID: 22464855; Google Scholar]

11. Falfushynska H., Gnatyshyna L., Yurchak I., Sokolova I., Stoliar O. The effects of zinc nanooxide on cellular stress responses of the freshwater mussels Unio tumidus are modulated by elevated temperature and organic pollutants. Aquat. Toxicol., 2015; 162: 82-93. [DOI: https://doi.org/10.1016/j.aquatox.2015.03.006; PMID: 25781395; Google Scholar]

ISSN 1996-4536 (print) • ISSN 2311-0783 (on-line) • Біологічні Студії / Studia Biologica • 2019 • Том 13/№1 • С. 27-38 
12. Falfushynska H.I., Gnatyshyna L.L., Fedoruk O.O., Stoliar O.B. Variability of metallothioneins responses in freshwater mussels exposed to trace metals or thiocarbamate pesticide. Sci. Lett. J., 2014; 3: 67.

13. Gnatyshyna L., Falfushynska H., Bodilovska O., Oleynik O., Golubev A., Stoliar O. Metallothionein and glutathione in Lymnaea stagnalis determine the specificity of responses on the effects of ionising radiation. Radioprotection, 2012; 47(2): 231-242.

[DOI: https://doi.org/10.1051/radiopro/2012004; Google Scholar]

14. Gnatyshyna L.L., Fal'fushynska H.I., Golubev A.P., Dallinger R., Stoliar O.B. The roles of metallothioneins in adaptation of pulmonate mollusk Lymnaea stagnalis under condition of environmental pollution. Hydrobiol. J., 2011; 47 (5): 56-66.

[DOI: https://doi.org/10.1615/HydrobJ.v47.i5.50; Google Scholar]

15. Golubev A., Afonin V., Maksimova S., Androsov V. The current state of pond snail Lymnaea stagnalis populations from water reservoirs of the Chernobyl nuclear accinent zone. Radioprotection, 2005; 40(S1): 511-517.

[DOI: https://doi.org/10.1051/radiopro:2005s1-075; Google Scholar]

16. Gonçalves S.F., Davies S.K., Bennet M., Raab A., Feldmann J., Kille P., Loureiro S., Spurgeon D., Bundy J.G. Sub-lethal cadmium exposure increases phytochelatin concentrations in the aquatic snail Lymnaea stagnalis. Sci. Total Environ., 2016; 568: 1054-1058.

[DOI: https://doi.org/10.1016/j.scitotenv.2016.06.149; PMID: 27358197; Google Scholar]

17. Guerlet E., Ledy K., Giambérini L. Field application of a set of cellular biomarkers in the digestive gland of the freshwater snail Radix peregra (Gastropoda, Pulmonata). Aquat. Toxicol., 2006; 77(1): 19-32.

[DOI: https://doi.org/10.1016/j.aquatox.2005.10.012; PMID: 16330108; Google Scholar]

18. Hispard F., Schuler D., deVaufleury A., Scheifler R., Badot P.M., Dallinger R. Metal distribution and metallothionein induction after cadmium exposure in the terrestrial snail Helix aspersa (Gastropoda, Pulmonata). Environ. Toxicol. Chem., 2008; 27(7): 1533-1542.

[DOI: https://doi.org/10.1897/07-232.1; PMID: 18384240; Google Scholar]

19. Hylland K. Biological effects of contaminants: Quantification of metallothionein (MT) in fish liver tissue. Denmark: ICES Techniques in Marine Environmental Sciences, 1999. 18 p. [DOI: http://dx.doi.org/10.25607/OBP-273; Google Scholar]

20. Leung K.M., Ibrahim H., Dewhurst R.E., Morley N.J., Crane M., Lewis J.W. Concentrations of metallothionein-like proteins and heavy metals in the freshwater snail Lymnaea stagnalis exposed to different levels of waterborne cadmium. Bull. Environ. Contam. Toxicol., 2003; 71(5); 1084-1090.

[DOI: https://doi.org/10.1007/s00128-003-8856-3; PMID: 14705673; Google Scholar]

21. Lowry O.H., Rosebrough H.J., Farr A.L., Randall R.J. Protein measurement with Folin phenol reagent. J. Biol. Chem., 1951; 193: 265-275 [PMID: 14907713; Google Scholar]

22. Lukowiak K., Sunada H., Teskey M., Lukowiak K., Dalesman S. Environmentally relevant stressors alter memory formation in the pond snail Lymnaea. J. Exp. Biol., 2014; 217: 76-83. [DOI: https://doi.org/10.1242/jeb.089441; Google Scholar]

23. Melgar C., Geissen V., Cram S., Sokolov M., Bastidas P., Ruiz Suárez L.E., Que Ramos F.G., Sanchez A.J. Pollutants in drainage channels following long-term application of Mancozeb to banana plantations in southeastern Mexico. J. Plant. Nutr. Soil. Sci., 2008; 171(4): 597-604. [DOI: https://doi.org/10.1002/jpln.200700171; Google Scholar]

24. Niederwanger M., Calatayud S., Zerbe O., Atrian S., Albalat R., Capdevila M., Palacios Ò., Dallinger R. Biomphalaria glabrata metallothionein: Lacking metal specificity of the protein and missing gene upregulation suggest metal sequestration by exchange instead of through selective binding. Int. J. Mol. Sci., 2017; 18(7): 1457.

[DOI: https://doi.org/10.3390/ijms18071457; PMID: 28684706; Google Scholar]

25. Nielson K.B., Winge D.R. Preferential binding of copper to the beta domain of metallothionein. J. Biol. Chem., 1984; 259: 4941-4946.

[PMID: 6715331; Google Scholar]

ISSN 1996-4536 (print) • ISSN 2311-0783 (on-line) • Біологічні Студії / Studia Biologica • 2019 • Том 13/№1 • С. 27-38 
26. Palacios Ò., Pagani A., Pérez-Rafael S., Egg M., Höckner M., Brandstätter A., Capdevila M., Atrian S., Dallinger R. Shaping mechanisms of metal specificity in a family of metazoan metallothioneins: evolutionary differentiation of mollusc metallothioneins. BMC Biol., 2011; 9: 4. [DOI: https://doi.org/10.1186/1741-7007-9-4; Google Scholar]

27. Palacios O., Pérez-Rafael S. Pagani A., Dallinger R., Atrian S., Capdevila M. Cognate and noncognate metal ion coordination in metal-specific metallothioneins: the Helix pomatia system as a model. J. Biol. Inorg. Chem., 2014; 19 (6): 923-935.

[DOI: https://doi.org/10.1007/s00775-014-1127-4; PMID: 24687203; Google Scholar]

28. Regoli F., Gorbi S., Fattorini D., Tedesco S., Notti A., Machella N., Bocchetti R., Benedetti M., Piva F. Use of the land snail Helix aspersa as sentinel organism for monitoring ecotoxicologic effects of urban pollution: an integrated approach. Environ. Health Perspect., 2006; 114 (1): 63-69.

[DOI: https://doi.org/10.1289/ehp.8397; PMID: 16393660; Google Scholar]

29. Ren Y., Smith A. Mechanism of metallothionein gene regulation by heme-hemopexin. Roles of protein kinase C, reactive oxygen species, and cis-acting elements. J. Biol. Chem., 1995; 270(41): 23988-23995.

[DOI: https://doi.org/10.1074/jbc.270.41.23988;·PMID: 7592595; Google Scholar]

30. Riera H., Afonso V., Collin P., Lomri A. A central role for JNK/AP-1 pathway in the pro-oxidant effect of pyrrolidine dithiocarbamate through superoxide dismutase 1 gene repression and reactive oxygen species generation in hematopoietic human cancer cell line U937. PLoS One, 2015; 10(5): e0127571.

[DOI: https://doi.org/10.1371/journal.pone.0127571; PMID: 25996379; Google Scholar]

31. Roesijadi G., Fowler B. Purification of invertebrate metallothioneins. Met. Enzymol., 1991; 205: 263-273.

[DOI: https://doi.org/10.1016/0076-6879(91)05106-6; PMID: 1779786; Google Scholar]

32. Shuhaimi-Othman M., Nur-Amalina R., Nadzifah Y. Toxicity of metals to a freshwater snail, Melanoides tuberculata. Sci. World J., 2012; 2012: 125785.

[DOI: https://doi.org/10.1100/2012/125785; PMID: 22666089; Google Scholar]

33. Srivastava A.K., Ali W., Singh R., Bhui K., Tyagi S., Al-Khedhairy A.A., Srivastava P.K., Musarrat J., Shukla Y. Mancozeb-induced genotoxicity and apoptosis in cultured human lymphocytes. Life. Sci., 2012; 90: 815-824.

[DOI: http://dx.doi.org/10.1016/j.Ifs.2011.12.013; PMID: 22289270; Google Scholar]

34. Sunderman F.W.Jr., Fraser C.B. Effects of nickel chloride and diethyldithiocarbamate on metallothionein in rat liver and kidney. Ann. Clin. Lab. Sci., 1983; 13(6): 489-495.

[PMID: 6318649; Google Scholar]

35. Viarengo A., Lowe D., Bolognesi C., Fabbri E., Koehler A. The use of biomarkers in biomonitoring: a 2-tier approach assessing the level of pollutant-induced stress syndrome in sentinel organisms. Comp. Biochem. Physiol. C Toxicol. Pharmacol., 2007; 146: 281-300. [DOI: https://doi.org/10.1016/j.cbpc.2007.04.011; PMID: 17560835; Google Scholar]

36. Viarengo A., Ponzano E., Dondero F., Fabbri R. A simple spectrophotometric method for metallothionein evaluation in marine organisms: an application to Mediterranean and Antarctic Molluscs. Mar. Environ. Res., 1997; 44(1): 69-84.

[DOI: https://doi.org/10.1016/S0141-1136(96)00103-1; Google Scholar] 


\title{
ОЦІНКА ВІДПОВІДІ МЕТАЛОТІОНЕЇНІВ СТАВКОВИКА ОЗЕРНОГО LYMNAEA STAGNALIS НА ВПЛИВ МЕТАЛІВ І ТІОКАРБАМАТНОГО ФУНГІЦИДУ
}

\author{
Л. Л. Гнатишина
}

ДВНЗ “Тернопільський державний медичний університет імені І. Я. Горбачевського” вул. Майдан Волі, 1, Тернопіль 46001, Україна

Тернопільський національний педагогічний університет імені Володимира Гнатюка вул. М. Кривоноса, 2, Тернопіль 46027, Україна e-mail: gnatyshynall@tdmu.edu.ua

Легеневим молюскам притаманний високий рівень поглинання розчинених металів і високий ступінь їхнього зв'язування, в основному Cd, Zn i Cu металодепонуючими білками металотіонеїнами (МТ). Однак більшість досліджень орієнтовані на наземні види, тоді як водяні равлики вивчені мало. Відтак, основною метою дослідження було оцінити специфічність металозв'язуючої функціїі металотіонеїну (MT) у ставковика озерного Lymnaea stagnalis. Протягом 14 днів проводили експози-

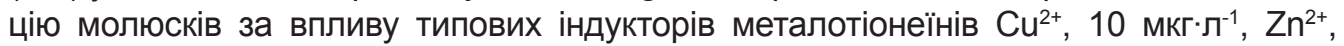

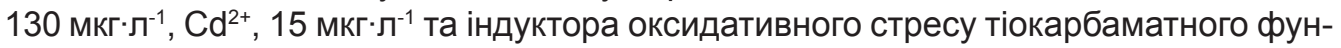
гіциду Татту, 91 мкг·л ${ }^{-1}$. Застосовані концентрації в експериментах відповідали їхнім екологічно реальним концентраціям. Було проаналізовано концентрації металів і характеристики металотіонеїнів травної залози. У нашій роботі за впливу всіх досліджених металів спостерігали підвищення концентрації металів (Zn, Cu або Cd) у тканинах і загальний рівень металотіонеїнів, визначених за тіоловими групами (MT-SH). Особливо за дії всіх металів у приблизно 2-3 рази підвищився вміст Zn у тканинах. Рівень металовмісної форми МТ (MT-Me) збільшився за дії Cd. Водночас, вплив Татту на рівень металів і MT-SH у тканинах був незначним, але викликав перерозподіл металів між металотіонеїнами (збільшення) та іншими сполуками. Зміна профілю елюйованих металотіонеїнів на DEAE-целюлозі було показано за впливу всіх чинників. Підсумовуючи, молюски продемонстровали широкий спектр відповіді та зіставлення різних характеристик залежно від експозиції. Відповіді на вплив металів і Татту відрізнялися за концентрацією металотіонеїнів. Проте основні причини впливу тіокарбаматів на гомеостаз металів потребують подальших досліджень.

Ключові слова: легеневий молюск, мікроелементи, тіокарбаматний фунгіцид, токсичність

Одержано: 28.03.2019

ISSN 1996-4536 (print) • ISSN 2311-0783 (on-line) • Біологічні Студії / Studia Biologica • 2019 • Том 13/№1 • С. 27-38 